\title{
Mapping of human and murine genes for latent TGF- $\beta$ binding protein-2 (LTBP2)
}

\author{
X. Li, ${ }^{1}$ W. Yin, ${ }^{3}$ L. Pérez-Jurado, ${ }^{2}$ J. Bonadio, ${ }^{3}$ U. Francke ${ }^{1,2}$ \\ ${ }^{1}$ Howard Hughes Medical Institute, Beckman Center, Stanford University Medical Center, Stanford, California 94305-5428, USA \\ ${ }^{2}$ Departments of Genetics and Pediatrics, Stanford University Medical Center, Stanford, California 94305-5428, USA \\ ${ }^{3}$ Department of Pathology, University of Michigan, Ann Arbor, Michigan 48109-0650, USA
}

Received: 25 July 1994 / Accepted: 1 September 1994

\begin{abstract}
A novel gene, isolated because of structural similarities to fibrillin, was called LTBP2 when its 4.6-kb transcript was found to encode a protein sequence related to the latent TGF- $\beta$ binding protein (LTBP1), which is encoded on human chromosome (Chr) 2 , region $\mathrm{p} 12-\mathrm{q} 22$. We have assigned the human and murine LTBP2 loci to regions of conserved synteny on human Chr 11 and mouse Chr 19. By PCR analysis of somatic cell hybrid DNA and fluorescence in situ hybridization, LTBP2 was mapped to human Chr band $11 \mathrm{q} 12$ and $L t b p 2$ to mouse Chr band 19B. Differences between inbred strains were discovered by single-strand conformation analysis of PCR products from the $3^{\prime}$ untranslated region. Analysis of BXD and AKXL recombinant inbred strains have placed Ltbp2 between D19Rp19 and $L y 10$ on proximal mouse Chr 19.
\end{abstract}

\section{Introduction}

A family of small related proteins, consisting of transforming growth factor (TGF) $\beta 1, \beta 2, \beta 3$ and others, have both stimulatory and inhibitory effects on growth of different cell types and play a role in the production and degradation of the extracellular matrix (Roberts and Sporn 1990; Lyons and Moses 1990). TGF- $\beta$ molecules are secreted in the form of latent large MW complexes that contain other proteins, such as latent TGF- $\beta 1$ binding protein (LTBP1). LTBP1 is covalently bound to extracellular matrix and, thus, mediates the matrix binding of TGF- $\beta$ (Taipale et al. 1994). The structure of human LTBP1 resembles fibrillin in that it includes 16 epidermal growth factor-like repeats and three copies of a novel 8-cysteine motif (Kanzaki et al. 1990; Maslen et al. 1991; Pereira et al. 1993). LTBP purified from different tissues may have different sizes owing to either proteolytic cleavage or alternative splicing (Kanzaki et al. 1990). A single LTBP1 locus appears to exist in the human genome that has been mapped to Chr 2 , region p12-q22 (Stenman et al. 1994). The gene has not yet been mapped in the mouse.

A structurally and functionally related gene has recently been identified, called LTBP2, that encodes a $4.6-\mathrm{kb}$ transcript in mouse embryo tissues ( $Y$ in et al. submitted). The predicted gene product is a secreted protein of 1252 amino acids that binds TGF- $\beta$. The mouse Ltbp2 sequence is only about $40 \%$ identical to the human LTBP1 sequence, but important domain structures are conserved, including the cysteine spacing in 13 EGF-like repeats.

To gain insight into the evolution of gene families and to identify candidate genes for human disorders and murine mutations, we are systematically mapping interesting genes in both species. Of relevance here, we have previously found that the genes for TGF- $\beta 1$, TGF- $\beta 2$, and TGF- $\beta 3$ are dispersed on different

Correspondence to: $\mathbf{U}$. Francke chromosomes in human and mouse (Fujii et al. 1986; Barton et al. 1988) and that genes for fibrillin- 1 and fibrillin- 2 are on different chromosomes in mouse, in regions of homology with the human loci (Li et al. 1993). Here, we report that the human (HSA) and murine (MMU) LTBP2 genes are asyntenic with LTBP1 (in human) and are located in small regions of conserved synteny on HSA $11 \mathrm{q} 12$ and MMU 19B.

\section{Materials and methods}

Somatic cell hybrid panels and PCR amplifications

For primary assignment of the LTBP2 gene to a human chromosome, we performed PCR amplification on a panel of 16 human $\times$ Chinese hamster hybrid cell lines derived from several independent fusion experiments (summarized in Francke et al. 1986). To distinguish the human-specific PCR product from amplified hamster sequences, the PCR primers were designed from human genomic sequences. The forward primer was $5^{\prime}$ GTGGGCGGGGAGTTCACAGTT (8954A) and the reverse primer $5^{\prime}$ CCTGTGACCTGAGTGGGACGA (9232A). The PCR conditions were $95^{\circ} \mathrm{C}, 5 \mathrm{~min}$; then 35 cycles of $94^{\circ} \mathrm{C}, 1 \mathrm{~min} ; 62^{\circ} \mathrm{C}, 1 \mathrm{~min} ; 72^{\circ} \mathrm{C}, 1 \mathrm{~min}$; followed by $72^{\circ} \mathrm{C}, 7 \mathrm{~min}$. The specificity of the 233 -bp PCR product was verified by restriction analysis with three different enzymes.

To assign the Ltbp2 gene to a mouse chromosome, we analyzed a mapping panel consisting of 14 mouse $\times$ Chinese hamster and two mouse $x$ rat somatic cell hybrid lines. The hybrids were derived from four independent fusion experiments as described previously (Francke et al. 1977; Francke and Taggart 1979; Joyner et al. 1985). The PCR primers were derived from the 3 -untranslated region of the murine $L t b p 2$ sequences with the forward primer $\left(5^{\prime}\right.$-CACTGAAAGTGGAGACAGACAAGT) (1416C) and the reverse primer $\left(5^{\prime}\right.$-TCCCGGCGGATGTATTTATTGTAC) (1413C). PCR was performed as described above except that the annealing temperature was $60^{\circ} \mathrm{C}$.

\section{Fluorescence in situ hybridization}

The chromosomal locations of the human and murine LTBP2 genes were independently determined by fluorescence chromosomal in situ hybridization as previously described (Milatovich et al. 1991). Briefly, lambda clones containing human or mouse LTBP2 sequences were labeled with biotin-11-dUTP by nick translation with commercial reagents (Boehringer Mannheim). Labeled probes were hybridized at a concentration of $6 \mathrm{ng} / \mu 1$ (50 $\mu 1$ per slide) for human LTBP2 and $12 \mathrm{ng} / \mu 1$ for murine $L T B P 2$ to pretreated and denatured metaphase chromosomes from human lymphocyte culture or primary mouse embryo culture. Hybridization was performed in the presence of salmon sperm DNA and cold competitor, either human placental DNA or mouse NIH 3T3 cell DNA.

After washing, the slides were covered with avidin/FITC (Vector Laboratories) and amplified with biotinylated goat anti-avidin D antibody (Vector Laboratories), followed by another round of avidin/FITC treatment. Chromosomes were counterstained with $200 \mathrm{ng} / \mu \mathrm{l}$ propidium iodide in $2 \times$ SSC. Twenty metaphase spreads were analyzed under an Axiophot (Zeiss) epifluorescence microscope. Signals were counted as specific only 
when the fluorescent signal was seen on both chromatids of a chromosome. A cooled charge-coupled device (CCD) camera (Photometrics PM512)/ Macintosh computer system was used for digital imaging, with software supplied by Tim Rand (Yale University). Black and white photographs were generated from PICT files.

\section{PCR-SSCP analysis of recombinant inbred mouse strains}

The murine Ltbp 2 gene was integrated into the genetic map of mouse Chr 19 by genotyping two independent panels of recombinant inbred (RI) mouse strains, BXD and AKXL (DNA obtained from The Jackson Laboratory). Progenitor strains were screened for DNA variants within the 3'UTR region of LTBP2 by single-strand conformation analysis of PCR products as described (Poduslo et al. 1991). For PCR amplification, the same primers and conditions were employed as described above for the mapping experiments except that $20 \mu \mathrm{Ci}$ of ${ }^{35} \mathrm{~S}$-dATP was added to a $25-\mu \mathrm{I}$ reaction. The DNA was denatured by mixing $9 \mu \mathrm{l}$ PCR product with $1 \mu \mathrm{l}$ of $0.5 \mathrm{M} \mathrm{NaOH}, 10 \mathrm{mM}$ EDTA, and incubating in a $42^{\circ} \mathrm{C}$ waterbath for 5 min, followed by cooling on ice. The mixture was loaded with $1 \mu \mathrm{l}$ of formamide dye on to a $6 \%$ nondenaturing polyacrylamide gel containing $5 \%$ glycerol in $0.5 \times \mathrm{TBE}$ buffer. Electrophoresis was performed at $100 \mathrm{~W}$ maximum for $14 \mathrm{~h}$ at $8^{\circ} \mathrm{C}$ constant temperature. The gel was dried on a $3 \mathrm{MM}$ paper and exposed to X-ray film for $6-24 \mathrm{~h}$.

\section{Results}

\section{Assignment of human LTBP2 gene to Chr band 11 qI2}

Genomic DNA from a panel of 16 human $\times$ Chinese hamster hybrid cell lines was analyzed by PCR with primers that specifically amplified the human LTBP2 sequences. Under these PCR conditions no specific amplification was seen from hamster DNA. The LTBP2-specificity of the 233-bp PCR product was verified by endonuclease digestion. Single HaeIII and ApaI sites and two MspI sites were identified within the 233-bp DNA fragment at the expected positions, indicating that the PCR amplification was from human LTBP2 sequences (data not shown). The 233-bp PCR product was obtained only from hybrid cell lines that had retained human Chr 11, and all other human chromosomes were excluded by the presence of discordant hybrids (Table 1a). In addition, the LTBP2-specific PCR amplification was seen in one hybrid cell line containing only $11 \mathrm{q}$ but not in another hybrid cell line retaining only $11 \mathrm{p}$. These results indicated that the human LTBP2 gene is located on 11q.

Fluorescence in situ hybridization confirmed the LTBP2 gene assignment to Chr 11 and refined the physical map position. A specific fluorescent signal on both chromatids of a Chr 11 was seen in 23/30 metaphase cells analyzed. Nineteen of the 23 positive cells had a specific signal on both homologs. Based on an R-banding pattern produced by the incorporation of BrdU after synchronization and counterstaining with propidium iodide, the human LTBP2 gene was assigned to band 11q12 (Fig. 1A, C).
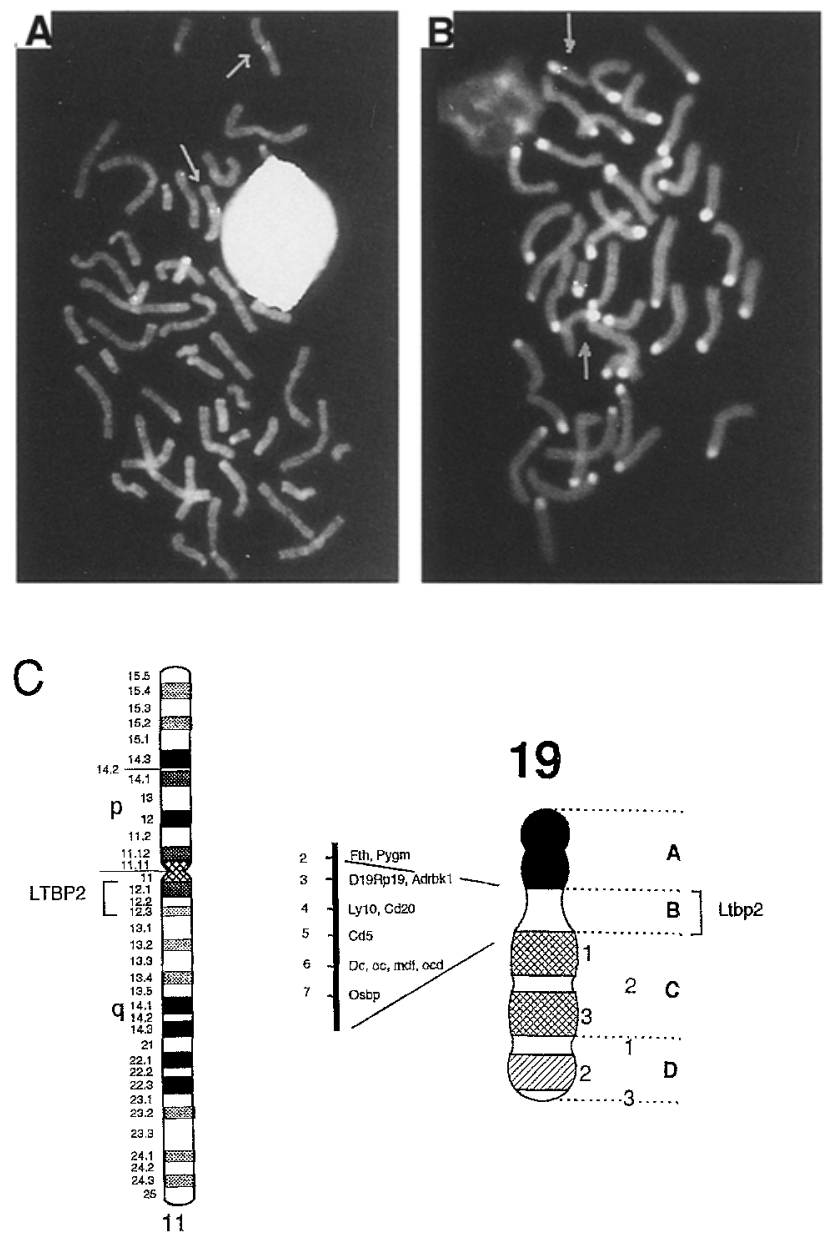

Fig. 1. Chromosomal localization of (A) human LTBP2 and (B) murine Ltbp2 by fluorescence in situ hybridization (FISH). Double chromatid signals (indicated by arrows) are present on human Chr 11 at band $q 12$ (A) and at a site corresponding to band B on mouse Chr 19 (B). (C) G-band idiograms of human Chr 11 (Francke 1994) and mouse Chrs 19 (Nesbitt and Francke 1973), illustrating the FISH localizations (indicated by brackets) of the human (LTBP2) and murine (Ltbp2) genes and other loci in the conserved region from consensus map of MMU19 (Guénet and Poirier 1993). The human homologous genes FTH1, PYGM, ADRBK1, CD20, $\mathrm{CD} 5$, and OSBP have been mapped to Chr 11 bands q12-q13.

\section{Assignment of murine Ltbp 2 to Chr band $19 B$ proximal to LylO}

By using primers derived from 3'UTR sequences of the murine Ltbp2 gene, a 381-bp DNA fragment was amplified from mouse genomic DNA. When the mapping panel of mouse $\times$ rodent hybrid cell lines was analyzed, the presence or absence of mouse Chr 19 in hybrid cell lines was in complete concordance with the murine

Table 1a. Comparison of human LTBP2 sequences with human chromosomes in human $\times$ hamster somatic cell hybrids

\begin{tabular}{|c|c|c|c|c|c|c|c|c|c|c|c|c|c|c|c|c|c|c|c|c|c|c|c|}
\hline \multirow{2}{*}{$\begin{array}{l}\text { LTBP2 } \\
\text { signal/chromosome }\end{array}$} & \multicolumn{23}{|c|}{ Human chromosome } \\
\hline & 1 & 2 & 3 & 4 & 5 & 6 & 7 & 8 & 9 & 10 & 11 & 12 & 13 & 14 & 15 & 16 & 17 & 18 & 19 & 20 & 21 & 22 & $\mathrm{X}$ \\
\hline \multicolumn{24}{|l|}{ Discordant hybrids } \\
\hline$+1-$ & 4 & 5 & 3 & 4 & 5 & 2 & 6 & 4 & 6 & 7 & 0 & 3 & 5 & 6 & 4 & 3 & 0 & 3 & 4 & 0 & 5 & 3 & 1 \\
\hline $\begin{array}{l}-1+ \\
\text { Concordant hybrids }\end{array}$ & 2 & \multicolumn{11}{|c|}{ Concordant hybrids } & 5 & 3 & 5 & 4 & 7 & 4 & & & & & 2 \\
\hline$t+$ & 4 & 3 & 5 & 3 & 4 & 6 & 1 & 5 & 1 & 2 & 7 & 6 & 4 & 6 & 4 & 5 & 2 & 5 & 7 & 7 & 6 & 7 & 2 \\
\hline$-1-$ & 5 & 6 & 2 & 3 & 7 & 3 & 6 & 3 & 5 & 7 & 7 & 5 & 1 & 1 & 3 & 2 & 7 & 4 & 3 & 7 & 2 & 3 & 2 \\
\hline Informative hybrids & 15 & 15 & 14 & 14 & 16 & 15 & 14 & 15 & 14 & 16 & 14 & 16 & 15 & 16 & 16 & 14 & 16 & 16 & 15 & 16 & 15 & 15 & 7 \\
\hline \% Discordance & 40 & 40 & 50 & 57 & 31 & 40 & 50 & 47 & 57 & 44 & 0 & 31 & 67 & 56 & 56 & 50 & 44 & 44 & 33 & 13 & 47 & 37 & 43 \\
\hline
\end{tabular}


Table 1b. Comparison of mouse $L b b 2$ sequences with mouse chromosomes in todent $\times$ mouse somatic cell hybrids

\begin{tabular}{|c|c|c|c|c|c|c|c|c|c|c|c|c|c|c|c|c|c|c|c|c|}
\hline \multirow{2}{*}{$\begin{array}{l}\text { Ltbp2 } \\
\text { product/chromosome }\end{array}$} & \multicolumn{20}{|c|}{ Mouse chromosome } \\
\hline & 1 & 2 & 3 & 4 & 5 & 6 & 7 & 8 & 9 & 10 & 11 & 12 & 13 & 14 & 15 & 16 & 17 & 18 & 19 & $\mathrm{X}$ \\
\hline \multicolumn{21}{|l|}{ Discordant hybrids } \\
\hline$+/-$ & 3 & 2 & 0 & 0 & 0 & 1 & 1 & 0 & 1 & 2 & 2 & 1 & 2 & 1 & 1 & 1 & 2 & 0 & 0 & 2 \\
\hline$-1+$ & 3 & 1 & 3 & 3 & 4 & 2 & 2 & 3 & 7 & 7 & 11 & 4 & 6 & 6 & 2 & 4 & 1 & 5 & 0 & 3 \\
\hline \multicolumn{21}{|l|}{ Concordant hybrids } \\
\hline$+1+$ & 7 & 10 & 8 & 7 & 5 & 7 & 8 & 8 & 4 & 3 & 0 & 7 & 4 & 5 & 9 & 6 & 10 & 5 & 10 & 7 \\
\hline$-1-$ & 2 & 3 & 5 & 5 & 5 & 4 & 4 & 5 & 4 & 3 & 3 & 4 & 3 & 4 & 4 & 4 & 3 & 5 & 5 & 3 \\
\hline Informative hybrids & 15 & 16 & 16 & 15 & 14 & 14 & 15 & 16 & 16 & 15 & 16 & 16 & 15 & 16 & 16 & 15 & 16 & 15 & 15 & 15 \\
\hline$\%$ Discordance & 40 & 19 & 19 & 20 & 29 & 21 & 20 & 19 & 50 & 60 & 81 & 31 & 53 & 44 & 19 & 33 & 19 & 33 & 0 & 33 \\
\hline
\end{tabular}

Data for chromosomes with rearrangements or present at low copy $(<0.1)$ were excluded. The \% discordance is calculated as the sum of discordant over total informative hybrids for each chromosome.

Table 2. Strain distribution patterns of $L t p b 2$ allele in recombinant inbred strains compared with neighboring loci

\begin{tabular}{|c|c|c|c|c|c|c|c|c|c|c|c|c|c|c|c|c|c|c|c|c|c|c|c|c|c|c|c|c|}
\hline \multirow[b]{2}{*}{ Strain no. } & \multicolumn{28}{|c|}{$\mathrm{AKR} / \mathrm{J} \times \mathrm{C} 57 \mathrm{~L} / \mathrm{I}(\mathrm{AKXL})$} \\
\hline & \multicolumn{2}{|c|}{5} & \multicolumn{2}{|l|}{6} & 7 & \multicolumn{2}{|l|}{8} & 9 & \multicolumn{2}{|c|}{12} & 13 & \multicolumn{2}{|c|}{14} & 16 & \multicolumn{2}{|c|}{17} & \multicolumn{2}{|l|}{19} & 21 & \multicolumn{2}{|l|}{24} & 25 & \multicolumn{2}{|c|}{28} & 29 & \multicolumn{2}{|c|}{37} & 38 \\
\hline DI9Rp19 & & d & A & & A & $\begin{array}{l}A \\
x\end{array}$ & & A & A & & $\mathrm{L}$ & A & & $\mathrm{L}$ & L & & $\mathrm{L}$ & & $\mathrm{L}$ & A & & A & A & & A & A & & $\mathrm{L}$ \\
\hline Xmmv 42 & & 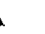 & A & & A & $\mathrm{L}$ & & A & A & & $\mathrm{L}$ & A & & $\mathrm{L}$ & L & & $\mathrm{L}$ & & $\mathrm{L}$ & A & & A & A & & A & A & & $\mathrm{L}$ \\
\hline Ltbp2 & & 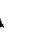 & A & & A & L & & A & A & & $\tilde{\mathrm{L}}$ & A & & $\mathrm{L}$ & L & & L & & $\mathrm{L}$ & A & & A & A & & A & A & & L \\
\hline Ly 10 & & 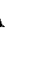 & A & & A & $\mathrm{L}$ & & $\mathrm{A}$ & $\mathrm{U}$ & & $\mathrm{L}$ & A & & $\mathrm{L}$ & $\mathrm{L}$ & & $\bar{L}$ & & $\mathrm{~L}$ & A & & A & $\begin{array}{l}A \\
\times\end{array}$ & & A & A & & L \\
\hline$C d 5$ & & 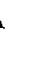 & A & & A & $\mathrm{L}$ & & A & A & & A & A & & $\mathrm{L}$ & L. & & $\mathrm{L}$ & & $\mathrm{L}$ & A & & $\begin{array}{l}A \\
x\end{array}$ & $\hat{L}$ & & $\mathrm{~A}$ & A & & $\mathrm{L}$ \\
\hline Fcerlb & & 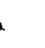 & A & & A & $\mathrm{L}$ & & A & A & & A & A & & $\mathrm{L}$ & L & & $L$ & & $\mathrm{~L}$ & A & & $\mathrm{L}$ & $\mathrm{L}$ & & A & A & & $\mathrm{L}$ \\
\hline \multirow{2}{*}{$\begin{array}{l}\text { Strain } \\
\text { no. }\end{array}$} & \multicolumn{28}{|c|}{$\mathrm{C} 57 \mathrm{BL} / 6 \mathrm{~J} \times \mathrm{DBA} / 2 \mathrm{~J}(\mathrm{BXD})$} \\
\hline & 1 & 2 & 3 & 4 & 5 & 6 & 8 & 9 & 11 & 12 & 13 & 14 & 15 & 16 & 18 & 19 & 20 & 21 & 22 & 23 & 24 & 25 & 27 & 28 & 29 & 30 & 31 & 32 \\
\hline$D 19 B y u 2$ & D & B & & & B & $\mathrm{D}$ & $\mathrm{D}$ & B & B & $\mathrm{B}$ & $\mathrm{D}$ & B & $\mathrm{B}$ & B & B & B & $\mathrm{D}$ & $\mathrm{B}$ & B & $\mathrm{D}$ & $\begin{array}{l}D \\
x\end{array}$ & B & $\mathrm{D}$ & B & $\bar{B}$ & $\mathrm{D}$ & $\mathrm{D}$ & $\mathrm{B}$ \\
\hline DI9Rp19 & D & B & & & B & $\mathrm{D}$ & $\mathrm{D}$ & $\mathrm{B}$ & B & $\mathrm{B}$ & $\mathrm{D}$ & B & B & B & B & B & $\begin{array}{l}D \\
\times\end{array}$ & B & $\mathrm{B}$ & $\mathrm{D}$ & $\hat{\mathrm{D}}$ & B & $\mathrm{D}$ & B & B & B & $\mathrm{D}$ & B \\
\hline DI9Byul & $\begin{array}{l}D \\
x\end{array}$ & B & & & B & $\mathrm{D}$ & D & $\mathrm{B}$ & B & $\mathrm{B}$ & $\begin{array}{l}D \\
x\end{array}$ & $\mathrm{~B}$ & B & в & B & B & $\mathrm{B}$ & B & B & D & $\mathrm{D}$ & B & $D$ & B & B & $B$ & $\begin{array}{l}D \\
x\end{array}$ & $\begin{array}{l}\mathrm{B} \\
\times\end{array}$ \\
\hline Ltbp 2 & $\begin{array}{l}B \\
\times\end{array}$ & B & & & B & $\mathrm{D}$ & D & B & B & B & $\begin{array}{l}B \\
\times\end{array}$ & $\mathrm{B}$ & B & B & B & $\mathrm{B}$ & $\begin{array}{l}B \\
\times\end{array}$ & B & B & D & $\mathrm{D}$ & B & $D$ & B & B & B & $\begin{array}{l}B \\
x\end{array}$ & $\begin{array}{l}D \\
x\end{array}$ \\
\hline Ly10 & $\begin{array}{l}D \\
\times\end{array}$ & B & & & B & $\mathrm{D}$ & D & B & B & B & $\mathrm{D}$ & B & B & B & B & B & D & B & B & D & $\mathrm{D}$ & B & U & B & B & $\begin{array}{l}B \\
\times\end{array}$ & D & B \\
\hline D19Mit22 & B & B & B & D & B & $D$ & $\mathrm{D}$ & B & B & $\mathrm{B}$ & D & B & $\mathrm{B}$ & B & B & B & D & B & B & $\mathrm{D}$ & $\mathrm{D}$ & B & $\mathrm{D}$ & B & B & D & D & B \\
\hline$C d 5$ & B & B & B & D & B & $\mathrm{D}$ & $\mathrm{D}$ & B & $\begin{array}{l}B \\
\times\end{array}$ & $\mathrm{B}$ & $\mathrm{D}$ & B & B & B & B & $\mathrm{B}$ & D & B & $\mathrm{B}$ & $\mathrm{D}$ & $\mathrm{D}$ & B & $\mathrm{D}$ & B & B & $\mathrm{D}$ & $\mathrm{D}$ & B \\
\hline$O s b p$ & B & B & B & D & B & D & $\mathrm{D}$ & $\mathrm{B}$ & D & B & $\mathrm{D}$ & B & B & B & B & B & D & B & B & $\mathrm{D}$ & D & $\mathrm{B}$ & $D$ & B & B & $\mathrm{D}$ & $\mathrm{D}$ & B \\
\hline
\end{tabular}

Ltbp2-specific amplification. All other mouse chromosomes were excluded by at least $19 \%$ discordant hybrids (Table 1b).

Fluorescence in situ hybridization was used to sublocalize the Ltbp2 gene on mouse Chr 19. Among 30 metaphase cells analyzed, a specific fluorescent signal on both chromatids of a Chr 19 was seen in 19 metaphases, 12 of which carried signal on both homologs. The site of hybridization was just distal to the centromeric heterochromatin region, and, therefore, the Ltbp 2 gene was assigned to Chr band 19B (Fig. 1B, C).

PCR-SSCA revealed a biallelic polymorphism with distinguishable patterns between $\mathrm{AKR} / \mathrm{J}$ and $\mathrm{C} 57 \mathrm{~L} / \mathrm{J}$, and between C57BL/6J and DBA/2J, indicating that both $\mathrm{AKXL}$ and $\mathrm{BXD}$ panels of recombinant inbred strains should be informative (data not shown). When the panels were typed and the Ltbp2 strain distribution patterns compared with all SDPs in Ben Taylor's database, the localization to $\mathrm{Chr} 19$ was confirmed. Comparison with SDPs of the AKXL panel, published in Guénet and Poirier (1993), places $L t b p 2$ into the $D 19 R p 19-C d 5$ interval with no recombinants between $L t b p 2$ and $X m m v 42$ or $L y 10$ (0/18 and 0/17, respectively; Table 2). Analysis of the BXD RI strains supports a position of Ltbp 2 in the D19Rp1-Ly10 interval, on either side of D19Byul, even though double-crossovers are present in strains $1,13,31$, and
32 (Table 2). When $L t b p 2$ typing of the BXD strains was repeated twice, consistent results were obtained.

\section{Discussion}

In this study we have assigned the human and murine LTBP2 genes to specific chromosomal positions by several independent approaches, including PCR analysis of interspecies somatic cell hybrid panels, fluorescence in situ hybridization, and recombinant inbred strain mapping in the mouse. The results were completely consistent and are further supported by the existing comparative map. The fact that the loci were assigned to regions of conserved synteny is also consistent with the notion that the LTBP2 genes cloned from both species are likely to be true homologs. With only a small part of the human gene sequenced to date, this is not a trivial point given the existence of a family of genes with EGF and 8 -cysteine repeats. The human gene for the first latent TGF- $\beta 1$ binding protein discovered (LTBP1), which is related to LTBP2, was assigned to human Chr 2 by study of human $x$ rodent somatic cell hybrid lines and was further sublocalized to $2 \mathrm{p} 12-\mathrm{q} 22$ by a regional mapping panel of three hybrid cell lines which retain 
partially overlapping regions of Chr 2 (Stenman et al. 1994). No LTBP genes have previously been mapped in the mouse.

Here we have assigned the human LTBP2 gene to Chr 11 band q12. The murine $L t b p 2$ gene was mapped to mouse Chr 19, band $\mathrm{B}$, that approximately corresponds to map units 3-10 on the genetic map (Lyon and Kirby 1994). The most proximal $10 \mathrm{cM}$ of the maps of Lyon and Kirby (1994) and Guénet and Poirier (1993) contain about ten genes that are homologous to human genes assigned to human Chr bands 11q12-q13, including those depicted in Fig. 1c: $\beta$-adrenergic receptor kinase-1 (Adrbkl), ferritin heavy chain ( $F t h$ ), antigens $C d 5$ and $C d 20$, ciliary neurotrophic factor $(C n t f)$, and oxysterol binding protein $(O s b p)$.

To integrate the murine $L t b p 2$ gene into the genetic map of mouse Chr 19, we have searched for a polymorphism by PCRSSCP and have analyzed two panels of recombinant inbred strains. Although more double crossovers than expected were observed in the BXD panel, it is still possible to place $L t b p 2$ proximal to $L y I O$ in the center of the conserved homologous region. There are four mutant loci in this region, $D c, o c$, mdf and ocd. $D c$, dancer, is characterized by circling behavior in heterozygotes and by cleft lip and cleft palate in homozygotes that die at birth (Deol and Lane 1966). The recessive $o c$ phenotype consists of osteosclerosis with abnormal osteoclasts (Marks et al. 1985). Atrophy of muscle fibers leading to marked reduction of muscle mass characterizes the $m d f$, muscle deficient, homozygotes (Womack et al. 1980). ocd, osteochondrodystrophy, arose in the $\mathrm{C} 3 \mathrm{H} / \mathrm{HeSn}$ strain in 1980 and is a recessive disorder. Homozygotes have reduced body size, a short, slightly domed head, supination of the forefeet, disproportionately shortened long bones of the limbs, and a short thickened tail (Sweet and Bronson 1991). Given that LTBP2 may play a role in the regulation of connective tissue and extracellular matrix, as well as in maintaining TGF- $\beta$ present in tissues in a latent state, the $L t b p 2$ gene could be considered as a potential candidate for the ocd or the oc mutations.

Acknowledgments. This work was supported by the National Institutes of Health grants HG00298 (U. Francke) and AR40673 (J. Bonadio), an ESPE Fellowship (L Pérez-Jurado), and the Howard Hughes Medical Institute, of which $U$. Francke is an investigator and X. Li is an associate. We thank Dr. Ben Taylor for helpful advice.

\section{References}

Barton, D.E., Foellmer, B.E., Du, J., Tamm, J., Derynck, R., Francke, U. (1988). Chromosomal mapping of genes for transforming growth factors $\beta 2$ and $\beta 3$ in man and mouse: dispersion of TGF- $\beta$ gene family. Oncogene Res. 3, 323-331.

Deol, M.S., Lane, P.W. (1966). A new gene affecting the morphogenesis of the vestibular part of the inner ear in the mouse. J. Embryol. Exp. Morphol. 16, 543-558.

Francke, U. (1994). Digitized and differentially shaded human chromosome ideograms for genomic applications. Cytogenet. Cell Genet. 65, 206-219.

Francke, U., Taggart, R.T. (1979). Assignment of gene for cytoplasmic superoxide dismutase (Sod-I) to a region of chromosome 16 and of Hprt to a region of the $X$ chromosome in the mouse. Proc. Natl. Acad. Sci. USA 76, 5230-5233.

Francke, U., Lalley, P.A., Moss, W., Ivy, J., Minna, J.D. (1977). Gene mapping in Mus musculus by interspecies cell hybridization: assignment of the genes for tripeptidase- 1 to chromosome 10 , dipeptidase- 2 to chromosome 12 , and adenylate kinase- 1 to chromosome 2 . Cytogenet. Cell Genet. 19, 57-84.

Francke, U., Yang-Fang, T.L., Brissenden, J.E., Ullich, A. (1986). Chromosomal mapping of genes involved in growth control. Cold Spring Harbor Symp. Quant. Biol. 51, 855-866.

Fujii, D., Brissenden, J.E., Derynck, R., Francke, U. (1986). Transforming growth factor $\beta$ gene maps to human chromosome 19 long arm and to mouse chromosome 7. Somatic Cell Mol. Genet. 12, 281-288.

Guénet, J.-L., Poirier, C. (1993). Mouse Chromosome 19. Mamm. Genome 4 (Suppi.), S261-S268.

Joyner, A.C., Lebo, R.V., Kan, Y.W., Tjian, R., Cox, D.R., Martin, G.R. (1985). Comparative chromosome mapping of a conserved homeo box region in mouse and human. Nature 314, 173-175.

Kanzaki, T., Olofsson, A., Moren, A., Wernstedt, C., Hellman, U, Miyazono, K., Claesson-Welsh, L., Heldin, C.-H. (1990). TGF- $\beta 1$ binding protein: a component of the large latent complex of TGF- $\beta 1$ with multiple repeat sequences. Cell 61, 1051-1061.

Li, X., Pereira, L., Zhang, H., Sanguineti, C., Ramirez, F., Bonadio, J., Francke, U. (1993). Fibrillin genes map to regions of conserved mouse/ human synteny on mouse chromosomes 2 and 18 . Genomics 18, 667672.

Lyon, M.F., Kirby, M.C. (1994). Mouse chromosome atlas. Mouse Genome 91, 20-61.

Lyons, R.M., Moses, H.L. (1990). Transforming growth factors and the regulation of cell proliferation. Eur. J. Biochem. 187, 467-473.

Marks, S.C., Jr., Seifert, M.F., Lane P.W. (1985). Osteosclerosis, a recessive lethal mutation on chromosome 19 in the mouse. J. Hered. 76, 171-176.

Maslen, C.L., Corson, G.M., Maddox, B.K., Glanville, R.W. (1991). Partial sequence of a candidate gene for the Marfan syndrome. Nature 352, 334-337.

Milatovich, A., Travis, A., Grosschedl, R., Francke, U. (1991). Gene for lymphoid enhancer-binding factor 1 (LEF1) mapped to human chromosome 4 (q23-q25) and mouse chromosome 3 near Egf. Genomics 11, $1040-1048$.

Nesbitt, M.N., Francke, U. (1973). A system of nomenclature for band patterns of mouse chromosome. Chromosoma 41, 145-158.

Pereira, L., D'Alessio, M., Ramirez, F., Lynch, J.R., Sykes, B., Pangilinan, T., Bonadio, J. (1993). Genomic organization of the sequence coding for fibrillin, the defective gene product in Marfan syndrome. Hum. Mol. Genet. 2, 961-968.

Poduslo, S.E., Dean, M., Kolch, U., O'Brien, S.T. (1991). Detecting highresolution polymorphisms in human coding loci by combining PCR and single-strand conformation polymorphism (SSCP) analysis. Am. J. Hum. Genet. 49, 106-111.

Roberts, A.B., Sporn, M.B. (1990). Handbook of Experimental Pharmacology, Vol. 95, Part 1, M.B. Sporn, A.B. Roberts, eds. (Heidelberg: Springer-Verlag), pp. 419-472.

Stenman, G., Sahlin, P., Olofsson, A., Geurts van Kessel, A., Miyazono, K. (1994). Assignment of the gene encoding the latent TGF-beta-1-binding protein (LTBP21) to human chromosome 2, region p12-q22. Cytogenet. Cell Genet. 66, 117-119.

Sweet, H.O., Bronson, R.T. (1991). Osteochondrodystrophy (ocd): a new autosomal recessive mutation in the mouse. J. Hered. 82, 140-144.

Taipale, J., Miyazono, K., Heldin, C.-H., Keski-Oja, J. (1994). Latent transforming growth factor- $\beta 1$ associates to fibroblast extracellular matrix via latent TGF- $\beta$ binding protein. J. Cell Biol. 124, 171-181.

Womack, J.E., MacPike, A., Meier, H. (1980). Muscle deficient, a new mutation in the mouse. J. Hered. 71, 68.

Yin, W., Smiley, E., Germiller, J., Bonadio, J. (1994). Structure and expression pattern of a novel latent TGF-beta binding protein-like gene. J. Biol. Chem. submitted. 